\title{
Kasvihormonit ja lakan marjojen kehitys
}

Olavi Junttila

Soveltavan biologian laitos, PL 27,00014 Helsingin yliopisto, olavi.junttila@helsinki.fi

\begin{abstract}
Johdanto
Lakka (hilla, muurain; Rubus chamaemorus L.) on varsinkin pohjoisessa arvokas luonnonmarja. Lakan kaupallisen merkityksen takia sen viljelymahdollisuuksia on tutkittu varsinkin Norjassa mutta myös Suomessa (Rapp 1991, Pirinen 1998). Varhaisempi tutkimus pyrki selvittämään mahdollisuuksia lisätä lakkasatoja luontaisilla kasvupaikoilla mm. lannoituksen avulla, mutta viime vuosina tutkimuksessa on keskitytty lakan viljelymahdollisuuksien selvittämiseen. Norjassa on jo aloitettu kahden hede- ('Apollen' ja 'Apollto') ja kahden emilajikkeen ('Fjordgull' ja 'Fjellgull') kaupallinen monistus. Suomessa lakkatutkimusta tehdään Kuopion yliopistossa, jossa tutkitaan mm. mahdollisuuksia kehittää yksikotinen lakkalajike (Kokko, suullinen tiedonanto). Lakan kaksikotisuus ja onnistuneen pölytyksen riippuvuus sääolosuhteista ovat tekijöitä, jotka vaikeuttavat lakan viljelyyn ottoa. Yksikotinen lajike saattaa ratkaista nämä ongelmat. Partenokarppinen lajike, joka kehittää marjan ilman pölytystä, olisi toinen mahdollinen ratkaisu. Aikaisemmissa tutkimuksissa on osoitettu, että auksiini- ja/tai gibberelliinikäsittely indusoi partenokarppisen hedelmän useissa ruusukasvien heimoon kuuluvissa lajeissa (Moore and Ecklund 1975). Mainittujen kasvihormonien keskeinen merkitys hedelmänkehityksen säätelyssä on osoitettu lukuisissa tutkimuksissa ja tähän tietämykseen perustuen on partenokarppisuutta alettu kehittää myös geeniteknologian avulla (Varoquaux et al. 2000). Tämän tutkimuksen tavoitteena oli tehdä alustava selvitys kasvihormonien vaikutuksesta lakan marjojen kehittymiseen ja luoda siten perusta mahdollisen partenokarppisen lajikkeen kehittämiselle.
\end{abstract}

\section{Aineisto ja menetelmät}

Tutkimuksissa käytettiin sekä lajiketta 'Fjellgull' että useita luonnonvaraisia lakkakantoja. Pääosa käsittelykokeista tehtiin kasvihuoneessa. Taimet hyödettiin fytotronissa $\left(15^{\circ} \mathrm{C}\right.$, jatkuva valo, PAR $\left.150 \mu \mathrm{mol} \mathrm{m} \mathrm{m}^{-2} \mathrm{~s}^{-1}\right)$ ja auenneet kukat käsiteltiin etanoliin liuotetuilla hormoneilla $(10 \mu \mathrm{l} / \mathrm{kukka})$. Käsittelyissä käytettiin kaikkiaan yhdeksää erilaista gibberelliiniä ja kolmea erilaista auksiinia (indolyyli-3-etikkahappo, IAA, naftaleenietikkahappo, NAA, 2,4-dikloorifenoksihappo, 2,4-D). Kukkaa kohti annetut hormonimäärät vaihtelivat 0,1 ja $10 \mu \mathrm{g}: n$ välillä. Kussakin käsittelyssä oli 6-12 kukkaa ja useimmat käsittelyt testattiin kahdessa tai useammassa kokeessa. Osa kukista käsiteltiin vain etanolilla (negatiivinen kontrolli), osa pölytettiin käsin (positiivinen kontrolli). Marjat kypsyivät noin viisi viikkoa käsittelyn jälkeen.

Marjanaiheiden kehittymistä tutkittiin myös alustavissa in vitro kokeissa. Pintasterilisoidut hedelmänaiheet irrotettiin toisistaan ja kasvatettiin $20^{\circ} \mathrm{C}$ lämpötilassa MS-alustalla, johon oli lisätty auksiinia (NAA) ja/tai gibberelliiniä $\left(\mathrm{GA}_{3}\right)$.

Marjanaiheiden hormonipitoisuuksia tutkittiin näytteistä, jotka kerättiin pölytyksen jälkeen neljän päivän välein kolmen viikon ajan. Näytteet puhdistettiin ja niistä mitattiin IAA ja useiden gibberelliinien $\left(\mathrm{GA}_{19}, \mathrm{GA}_{20}, \mathrm{GA}_{1}, \mathrm{GA}_{29}, \mathrm{GA}_{8}\right.$ ja $\left.\mathrm{GA}_{4}\right)$ pitoisuudet kaasukromatografiamassaspektrometrillä.

\section{Tulokset ja tulosten tarkastelu}

Ensimmäisessä käsittelykokeessa käytettiin vain yhtä gibberelliiniä, $\mathrm{GA}_{3}$, joka on tavallisin kaupallinen gibberelliini. $\mathrm{GA}_{3}$-käsittely $(2,5-10 \mu \mathrm{g} / \mathrm{kukka})$ indusoi samanlaisen marjojen kehityksen kuin pölytys. Hormonikäsiteltyjen ja pölytettyjen marjojen välillä ei ollut tilastollisesti merkittäviä eroja kypsien marjojen painossa, mutta kylläkin siementen painossa $(\mathrm{P}<0.05)$. Pölytettyjen marjojen siementen tuorepaino oli noin $12 \mathrm{mg}$, mutta $\mathrm{GA}_{3}$ :lla indusoitujen marjojen siemenet painoivat vain noin $2 \mathrm{mg}$. Ero johtui ennen kaikkea siitä, että partenokarppisten marjojen siemenissä ei ollut alkiota, 
mutta myös siementä ympäröivä kuori, endokarppi, oli pienempi partenokarppissa $(2,5 \pm 0,22 \mathrm{mg})$ kuin pölytetyissä $(5,4 \pm 0,51 \mathrm{mg})$ siemenissä.

Nykyisin tunnetaan jo yli sata erilaista gibberelliiniä, mutta vain harva gibberelliini on itsessään biologisesti aktiivinen. $\mathrm{GA}_{1}$ on tärkein kasveista eristetty aktiivinen gibberelliini, sen lisäksi $\mathrm{GA}_{4}$ on biologisesti aktiivinen joissakin lajeissa. Näiden aktiivisten gibberelliinien synteesi perustuu pääasiassa kahteen erilaiseen synteesireittiin ja $\mathrm{GA}_{1}$ :n lähimpiä esiasteita ovat $\mathrm{GA}_{19}$ ja $\mathrm{GA}_{20}$, kun taas $\mathrm{GA}_{24}$ ja GA ovat vastaavasti $\mathrm{GA}_{4}$ :n esiasteita (Hedden and Kamiya 1999). Myös $\mathrm{GA}_{3}$ on biologisesti aktiivinen ja sekin on eristetty joistakin kasveista, mutta sekä sen synteesireitti että biologinen merkitys on epäselvä. $\mathrm{GA}_{5}$ voi olla yksi mahdollinen $\mathrm{GA}_{3}$ :n esiaste. Näille kolmelle biologisesti aktiiviselle gibberelliinille $\left(\mathrm{GA}_{1}, \mathrm{GA}_{4}\right.$ ja $\left.\mathrm{GA}_{3}\right)$ on yhteistä se, että niiden hiiliatomissa numero kolme on hydroksyyliryhmä $\beta$-asemassa. Kaikkien mainittujen gibberelliinien vaikutus lakan marjojen kehittymiseen tutkittiin kahdessa erillisessä kokeessa. Kokeissa oli mukana myös synteettinen

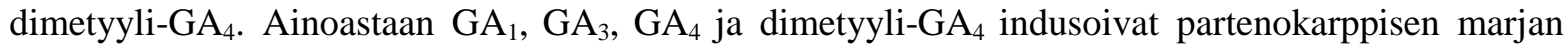
kehittymisen. Muiden testattujen gibberelliinien inaktiivisuus viittaa siihen, että lakan sikiäin ei pysty muuntamaan esiasteita aktiivisiksi gibberelliineiksi. Useissa gibberelliinien aktiivisuutta mittaavissa testeissä esimerkiksi $\mathrm{GA}_{19}$ ja $\mathrm{GA}_{20}$ ovat lähes yhtä aktiivisia kuin $\mathrm{GA}_{1}$ (Crozier et al. 1970, Junttila and Jensen 1988). Aktiivisten gibberelliinien välillä ei olllut tilastollisesti merkittäviä eroja, mutta dimetyyli-GA $\mathrm{G}_{4}$ oli kaikissa kokeissa hieman tehokkaampi kuin muut gibberelliinit. Dimetyyli-GA 4 :n suurempi aktiivisuus voi johtua siitä, että metyyliryhmät estävät hormonin metaboolista hajoamista.

$\mathrm{GA}_{3}$ testattiin myös kenttäkokeessa, jossa kukat ruiskutettiin hormoniliuoksella. Ruiskutus liuoksella, jonka väkevyys oli $500 \mathrm{mg}^{-1}$ indusoi partenokarppisten marjojen kehittymisen.

Auksiinilla on keskeinen vaikutus hedelmien kehittymiseen ja säätelemällä hedelmänaiheiden auksiinisynteesiä geenitekniikan avulla on jo saatu kehitettyä partenokarppisia kasveja esimerkiksi munakoisosta (Rotino et al. 1997) ja vadelmasta (Mezzetti et al. 2001). Käytetyt auksiinit eivät indusoineet partenokarppisten marjojen kehittymistä lakkalla, vaikka joissakin tapauksissa auksiini-käsittely aiheutti marjanaiheiden osittaista kehittymistä. Alustavat in vitro kokeet, joissa eristettyjä marjanaiheita kasvatettiin MS-alustalla, viittaavat siihen, että marjanaiheet vaativat kehittyäkseen sekä auksiinia että gibberelliiniä. Tässä yhteydessä on mielenkiintoista todeta, että vaikka auksiinikäsittelyllä ei ole saatu indusoitua partenokarppisuutta vadelmalla, tällainen vaikutus on todettu siirtogeenisissä taimissa joissa on lisätty auksiinisynteesiä marjanaiheissa (Mezzetti et al. 2001). Auksiinin ja gibberelliinin mahdollista yhteisvaikutusta lakan marjojen kehittymiseen tullaan tarkastelemaan tarkemmin jatkokokeissa.

Lakan marjanaiheista on eristetty IAA sekä gibberelliinit $\mathrm{A}_{19}, \mathrm{~A}_{20}, \mathrm{~A}_{1}, \mathrm{~A}_{29}, \mathrm{~A}_{8}$ ja $\mathrm{A}_{4}$. Tämä viittaa siihen, että lakassa saattaa olla useampia gibberelliinien synteesireittejä. Gibberelliinien pitoisuudet olivat korkeimpia heti pölyttymisen jälkeen, mutta ne eivät muuttuneet kovinkaan merkittävästi seuraavien kolmen viikon aikana. Sitä vastoin IAA-pitoisuus nousi tuona aikana varsin voimakkaasti.

\section{Johtopäätökset}

Suoritetut kokeet osoittavat, että gibberelliinikäsittelyllä voidaan saada partenokarppisia lakkoja. Tällainen käsittely voi siten korvata epäonnistuneen pölytyksen. Toistaiseksi ei ole tutkittu mahdollisuutta indusoida gibberelliinikäsittelyllä marjojen kehittyminen myös sellaisissa tapauksissa, joissa emikukat ovat lievästi vaurioituneet esimerkiksi hallan takia. Gibberelliini on luontainen hormoni lakan marjoissa, mutta jatkotutkimuksissa on selvitettävä käsittelyn vaikutuksia kypsien marjojen hormonipitoisuuksiin ja niiden laatuominaisuuksiin. Näissä käsittelykokeista saadut tulokset ja muilla kasveilla tehdyt siirtogeenitutkimukset viittaavat siihen, että lakastakin on mahdollista kehittää partenokarppisia lajikkeita.

\section{Kirjallisuus}

Crozier, A., Kuo, C. C., Durley, R. C., and Pharis, R. P. 1970. The biological activities 26 gibberellins in nine plant bioassays. Can. J. Bot. 48: 867-877. 
Hedden, P. and Kamiya, Y. 1999. Gibberellin biosynthesis: Enzymes, genes and their regulation. Annu. Rev. Plant Physiol. Plant Mol. Biol. 48: 432-460.

Junttila, O., and Jensen, E. 1988. Gibberellins and photoperiodic control of shoot elongation in Salix. Physiol. Plant. 74: 371-376.

Mezetti, B., Landi, L., and Spena, A. 2001. Biotechnology for improving Rubus production and quality. $8^{\text {th }}$ Intern. Rubus and Ribes Symposium, 9-11 July 2001, Dundee, . Abstract OP 8.

Moore, T. C. \& Ecklund, P. R. 1975. Role of gibberellins in the development of fruits and seeds. In: Krishnamoorthy, H. N. ed., Gibberellins and Plant Growth. Wiley Eastern Ltd., New Delhi, India, p. 145-182.

Pirinen, H. 1998. Lakan (Rubus chamaemorus L.) viljelymahdollisuudet Suomessa. Helsingin yliopisto, Kasvintuotantotieteen laitos, Puutarhatieteen julkaisuja 32, $37 \mathrm{~s}$.

Rapp, K. 1991. Selection for high berry yield, and development of varieties of cloudberry (Rubus chamaemorus L.). Norsk Landbruksforskn. 5: 359-367.

Rotino, G. L., Perri, E., Zottini, M., Sommer, H., and Spena, A. 1997. Genetic engineering of parthenocarpic plants. Nature Biotechn. 13: 1398-1401.

Varoquaux, F., Blanvillain, R., Delseny, M., and Gallois, P. 2000. Less is better: new approaches for seedless fruit production.. Trends in Biotechn. 18: 233-242. 